\title{
1 East Anglia: a linguistic history
}

As a modern topographical and cultural term, East Anglia refers to a region of England which has no official status. Like similar labels such as "The Midlands" (of England, or Ireland) or "The Midwest" (of the USA), the term is widely understood, but stands for an area which has no clear boundaries.

Most people would agree that today the English counties of Norfolk and Suffolk are prototypically East Anglian, although even here the status of the Fenland areas of western Norfolk and northwestern Suffolk is ambiguous: the Fens were for the most part uninhabited until the 17th century, as we shall discuss later, and the cultural orientations of this area are therefore less clear. The main issue, however, has to do with the extent to which all or parts of the neighbouring counties, notably Cambridgeshire and Essex, form part of East Anglia or not. As we shall see, East Anglia as a specifically linguistic area has also changed size and shape significantly over the centuries. But it is not controversial to assert that, linguistically, northeastern Essex and eastern Cambridgeshire (at least) belong with East Anglia; and in this book we will be examining data from both of these counties as well as from Norfolk and Suffolk. ${ }^{1}$

As we shall also see, the English of East Anglia has played an important role in the history of the English language; and East Anglia has a serious claim to be the first place in the world where English was ever spoken. East Anglia was one of the most densely populated areas of England for many centuries until the Industrial Revolution, Norwich, ${ }^{2}$ the major city in the region, was one of the three largest provincial cities in the country - and there was some input from the dialects of the region into Standard English. The area also played an important role in the development of colonial Englishes (see Chapter 6), notably the American English of New England.

But of course East Anglia has not always been English speaking.

\subsection{Brittonic}

The earliest language of East Anglia which we know anything about was Brittonic (or Brythonic). This was the British Celtic language which was the ancestor of the

1 The East Anglian Magazine, which was published in Ipswich, Suffolk, from 1935 to 1997, contained articles about, and advertising from, Norfolk, Cambridgeshire, Suffolk and Essex.

2 Pronounced /norid3/, rhyming with porridge. 
modern Brittonic languages Welsh, Cornish and Breton, and was formerly spoken all over the island of Britain.

It is not known with any degree of certainty when Celtic speakers first arrived in Britain, but Baldi \& Page (2006: 2194) say that the "traditional view of the settlement of the Celts places them in the British Isles no earlier than about 2000 BC”. Fortson (2010: 309) says, more cautiously, that the first identifiable Indo-Europeans who can actually be pinpointed archaeologically in western Europe are the Celts of the later stages of the Hallstatt culture in central Europe, from about $1200 \mathrm{BC}$, who according to him then arrived in southeastern England at some point after $1000 \mathrm{BC}$.

By the beginning of the first century $\mathrm{AD}$, the Brittonic-speaking peoples in and around East Anglia who we have any information about included the Corieltauvi, who occupied western Cambridgeshire, Northamptonshire and areas beyond, with their major centre on the site of modern Leicester; the Catuvellauni, who lived in Hertfordshire, Bedfordshire and southern Cambridgeshire, with Verlamion (St Albans) being their major settlement; the Trinovantes of Essex and southern Suffolk, with their capital at Camulodunon (Colchester); and the Iceni. The Iceni were the core East Anglian group, inhabiting the area that is now Norfolk together with neighbouring parts of Suffolk and Cambridgeshire. They are historically well known from their uprising, under the leadership of Queen Boudica, ${ }^{3}$ against the Romans. Their capital was known to the Romans as Venta Icenorum: Icenorum was the Latin genitive plural of the tribal name of the Iceni, so 'of the Iceni'; and venta was used in Brittonic as the name of important markets or meeting places. The same vent- form appears in the modern name of the Welsh town Caerwent. ${ }^{4}$ Remains of the Romano-British town on the site of Venta Icenorum are located today on the outskirts of the Norfolk village of Caistor St Edmunds, just to the south of Norwich.

As to whether there was any kind of distinctively East Anglian Brittonic, we can only guess. As Schrijver says, we lack "any knowledge about the peculiarities of the Celtic dialects that were spoken in, say, Kent, Essex, and East Anglia”, all of our information coming from a later date, by which time Brittonic was confined to the western and northern areas of Britain. But to suppose that there actually were differences between the Brittonic of eastern England and other areas would be a very good guess. Any language which is spoken over an area as large as Britain for a thousand years or more will develop significant

3 Boudīca was Brittonic for 'victorious'. The word survives in Modern Welsh as Buddug 'Victoria'.

4 Caer means 'fort', and derives from Latin castra (see below). 
regional dialect differences. And indeed "the little we know about eastern British Celtic points to it being closer to the Continental Celtic language of Gaul than to western British" (Schrijver, 2014: 31): there were "strong connections across the Channel, with the . . . Celtic of northern Gaul” (2014: 58).

The suspicion has to be, moreover, that there were significant differences within eastern British Celtic, including - as with the later English dialects - between southern and northern East Anglia. According to Williamson (2013), the archaeology of southern Suffolk for the period prior to the Roman conquest indicates numerous contacts with the Roman world, showing links to southeastern England and Gaul and thence to the Mediterranean. There are no such indications, however, for central and northern Suffolk or Norfolk. Williamson supposes that these differences in material culture were indicative of a political division also. The northern area was the land of the Iceni, whose leading families remained hostile to Rome after the conquest. Southwestern Suffolk, on the other hand, was the land of the Trinovantes, who also held Essex and eastern Hertfordshire. Walton Rogers (2012) writes that the boundary between the Iceni and the Trinovantes "has been placed in different positions by different authors, although all agree that it lay to the south of the current county border (between Norfolk and Suffolk)” (2012: 110). Martin (1999) believes that the boundary ran from east to west along the watershed north of the River Gipping ${ }^{5}$ and then along the valley of the River Lark. ${ }^{6}$ Fairclough (2010: 12) suggests that it might have run through Thornham Parva, in northern Suffok south of Scole, where a "Grim's Ditch"7 appears on medieval maps and where to this day a sunken lane by Thornham Parva churchyard runs along the same line. In any case, it would be a surprise if this political and cultural boundary, wherever it was exactly, was not also a Brittonic dialect boundary.

Surviving linguistic evidence for the centuries-long presence of Celtic speakers in East Anglia - probably somewhere between 1,500 and 2,500 years - is not especially great. What evidence there is includes several river names which are or may be of Brittonic origin, in spite of the fact that subsequent rather dense Germanic settlement (see 1.3.1) led to only "limited survival of the old British names for streams and rivers" (Fellows-Jensen, 2000: 46). The name of the Norfolk river Yare, which in Old English was called Gerne, is perhaps from a Celtic root ger- or gar- meaning 'babbling river' (Ekwall, 1928), or from a Celtic root meaning 'heron' cf. Modern Welsh garan 'heron, crane' (Breeze, 2006); in the relatively flat East

5 The Gipping rises near Mendlesham in Suffolk and flows through Stowmarket to Needham Market and on to Ipswich, where it becomes the Orwell.

6 The Lark rises near Stanningfield in Suffolk and flows through Bury St Edmunds and Mildenhall to the Great Ouse near Littleport in Cambridgeshire.

7 It is possible that the name Grim was a reference to the Devil. 
Anglian landscape, the slow-moving Yare does not exactly 'babble', so the latter seems more probable. The Latin name of the Roman Saxon-Shore fort at Burgh Castle by the river estuary was the Celtic-derived Gariannum (Sandred, 2001).

The British name of the River Chet in Norfolk was probably Lodn 'muddy', which survives today in the name of the small town of Loddon which the river flows through: the ancient Celtic root lut- meant 'mud'. The Great Ouse and Little Ouse rivers may derive their names from the ancient Celtic word for 'water', being related to the Scots Gaelic uisge 'water' which, in the form of uisge beatha 'water of life', is the origin of the word whisky (Ekwall, 1928). Other possiby Brittonic river names in the area are those of the Colne (Ekwall, 1928: 89), the Nene $^{8}$ (Ekwall, 1928: 300), and the Stour, ${ }^{9}$ which some writers have argued comes from a Celtic root sturr 'strong' (Ekwall, 1928: 378ff).

The evidence also includes a number of settlement names which have been retained from the time when Brittonic was the only language of the area. The Lynn in the name of the Norfolk town of King's Lynn is derived from British Celtic lïn 'pool', which in modern Welsh has become llyn 'lake'. The names of North and South Creake in Norfolk are related to Old Welsh creic, modern Welsh craig, 'rock'. Trunch in Norfolk is probably from British trum kēd, 'promontory wood', where kēd corresponds to modern Welsh coed 'wood' (Coates \& Breeze, 2000: 174). And there are two places in Norfolk called Eccles, which is cognate with Modern Welsh eglwys 'church'; Sandred (2001: 41) suggests that "the survival of this early Latin word in British form, *egles” is remarkable.

The British language continued to be spoken by Celts throughout the Roman occupation, which lasted for around four hundred years (see 1.2). And after the influx into East Anglia of West Germanic speakers from across the North Sea, beginning in a significant way from the 5th century, these were for several generations a linguistic minority living amongst or alongside a Brittonic-speaking majority, with a significant period of language contact and bilingualism. According to Laker (2008: 21), "there is much agreement from scholars working in neighbouring disciplines that there was significant survival of the RomanoBritish population in the fifth and sixth centuries". This would probably be less true of East Anglia than of areas further west and north; but Walton Rogers (2012) nevertheless argues on the basis of archaeological evidence that reverse acculturation, of Germanic Anglians to British culture, took place. The survival of a distinctive and cohesive culture well into the 500s AD in the former lands of the Iceni also shows that Celtic societies "may not have been

8 Pronounced both /ni:n/ and /nen/.

9 Most often pronounced to rhyme with tower, but also with sure. 
entirely overwhelmed by the incoming culture" (2012: 119). Many linguists, indeed, have supposed that some features of the Old English language which distinguish it from its continental cousins are the result of Celtic influence, resulting from generations of bilingualism (see Filppula et al, 2002). ${ }^{10}$

It is, revealingly, also true that, as the Germanic-speaking peoples established villages in East Anglia with typically West Germanic names ending with the generic (second) elements -ham and -ing, there also developed several old English place-names which confirm that British-speaking and Germanic-speaking peoples lived in some proximity to one other for some considerable time after the arrival of the Germanic speakers (Briggs, 2020a). The specific (first) element Bret- in the name Brettenham (one each in Norfolk and Suffolk) indicates that these villages were inhabited by British, i.e. Celtic-speaking, people. And the specific Wal- element in the names of places such as Walcott (Norfolk) and Walton (Norfolk and Suffolk) also all indicate the survival of Britons: Walcame from a Germanic form meaning 'foreigner' which survives in the modern English name of Wales (Welsh Cymru).

Britonnic linguistic survival is also perhaps indicated by the name of the area of central Norwich known as Coslany. This has been argued by Coates \& Breeze (2000) to derive from a Late British ${ }^{11}$ form köslönnī, from Early British ko-slunn-ijā, which was the form ancestral to Modern Welsh cystlynedd 'kindred, affinity, alliance', so in this case probably 'place where people live together, community'. Coates \& Breeze suggest that the name was adopted by Old English speakers around $550 \mathrm{AD}$ as the name of "a place of some significance in the geography of Celtic eastern Britain” (2000: 158).

However, it then seems that the Britons of East Anglia suffered a more organised and larger invasion by West Germanic peoples in $527 \mathrm{AD}$, and that a period of actual warfare followed between these invaders and the native Celts, descendants of the Iceni (Williamson, 1993). The Late British language did then eventually disappear from East Anglia, though it is thought to have survived in the Fens longer than elsewhere in southeastern England - until perhaps 650 AD or even after: Morris writes that "near Peterborough Guthlac was troubled about 705 by the still independent British of the Fenland" (1973: 314).

10 See Coates (2018) for a more sceptical view.

11 The Late British period is conventionally dated as starting from around $450 \mathrm{AD}$. 


\subsection{Latin and Northwestern Romance}

The first language after Brittonic to arrive in East Anglia was the Latin of the Romans, who invaded England in $43 \mathrm{AD}$, pushing northwards and reaching the edge of the Scottish Highlands by 80 AD or so. They appear to have taken control of East Anglia by around 47 AD.

By the time the official Roman occupation of England ended, over 350 years later in $\mathrm{AD} 410$, the Lowland zone of southern England was no longer simply monolingual Brittonic-speaking, according to Schrijver (2002). Indeed, there is evidence that some upper-class Britons had a acquired a knowledge of Latin even before the Roman invasion, through travel and trade. Certainly at the end of the Roman period, Latin was being spoken in one way or another by a good proportion of the lowland Christian Romano-British population.

In using the term lowland, Schrijver is referring to the Romanized area of England "which runs southeast of an approximate line that connects Dorchester, Bath, Gloucester, and Wroxeter and bends sharply eastwards towards Lincoln, then northwards past York until it hits Hadrian's Wall near Corbridge" (Schrijver, 2014: 32). It certainly includes, in other words, East Anglia.

A British form of Late Spoken Latin, Schrijver suggests (2002), was very widely used by the Celts, especially amongst the upper-classes. For some Celts, this would have been their native language, their communities having gone through a period of language shift in which they had gradually abandoned Brittonic as their mother tongue. Adams writes that "there is evidence . . . for the spread of Latin among the Celtic population" (2007: 622), and he describes "a Romanised Celtic population which had not received any sort of literary education" and mentions "lower social dialects [of Latin] as they were spoken in Britain". For other Celts, it would have been a second-language lingua franca used for communicating with Latin speakers and other language groups who were part of the Roman occupying forces.

The presence of a significant Romano-British elite in East Anglia is strongly indicated by the discovery in the Suffolk village of Hoxne, just south of the River Waveney and the border with Norfolk, of what is now known as the Hoxne Hoard. This is the largest hoard of Roman silver and gold ever found in Britain: it includes 200 pieces of sliver tableware, gold jewelry, and the biggest collection of gold and silver coins from the 300s and 400s AD ever found anywhere in the Roman Empire.

The British version of Late Spoken Latin disappeared from East Anglia along with British Celtic. Jackson (1953) cites Pogatscher (1888) as believing that there were Latin speakers in England until about 600, though this is more likely to have been in the north of the country than in East Anglia. According to Schrijver 
(2002), if this British Late Spoken Latin had survived somewhat longer, it would have ended up being very like Old French - he links together the Late Spoken Latin of Britain and northern France as Northwestern Romance: "the little that is known about the way in which Latin in Britain developed after the first century suggests that it did not differ substantially from the late Latin of Gaul, which ultimately became French" (2014: 33). He argues this point on the basis of a detailed phonological analysis of what British Latin was like as revealed by evidence of its influence on the Late British Celtic of Southeastern England.

In spite of the important role of Late Latin, however, the language of the Romans has left few traces in modern East Anglia. The place-names of Caister, near Great Yarmouth; Caistor-by-Norwich (Caistor Saint Edmund); Brancaster, in north Norfolk; and the -chester in Colchester, Chesterton (Cambridgeshire) and Godmanchester (Huntingdonshire), all go back to Latin castra, singular castrum, which originally referred to Roman military encampments. There are also place-names derived from the Latin word campus 'field', probably meaning 'enclosure', as in Bulcamp and Campsey, both in Suffolk (Briggs \& Kilpatrick, 2016; Briggs, 2020a). And vicus 'Roman settlement' survives in the name of the two Wickhams in modern Suffolk.

The Romans were famous for their construction of long straight paved roads, and the names of Stratton Strawless, Long Stratton, and Stradsett in Norfolk, as well as Stradbroke, Stradishall, and Stratford St Mary in Suffolk, go back to Latin strata 'paved road'. Long Stratton and Stratford St Mary both lay on the important East Anglian Roman road which led from Caistor St Edmund southwards towards the Roman capital of Camulodunum (the Latin form of the Brittonic name), modern Colchester, which now forms the basis of the modern A140 Norwich-Ipswich road and the A12 road from Ipswich to Colchester.

\subsection{West Germanic and Old English}

The English language which gradually replaced British Celtic and British Late Spoken Latin in East Anglia is today most closely related historically to four other modern languages: Frisian, Dutch, Low German, and - somewhat less closely German. These languages are all descended from a common parent language now known to linguists as West Germanic, which was spoken in what are now the Netherlands, Northern Germany and southern Denmark about 2,000 years ago.

During the 300s and 400s AD, boat-loads of West-Germanic-speaking people no doubt particularly men - started crossing the North Sea to the eastern shores of Britain. Some arrivals, in fact, had almost certainly come well before that: since the second century AD, the Romans had been employing Germanic mercenaries in 
their garrisons in Britain (Nielsen, 1998: 160). These Germanic people were members of the tribal groupings we now refer to as the Jutes, Angles, Saxons, and Frisians. They were mainly from coastal districts just across the North Sea from Britain. The Jutes came from the furthest north, from northern and central Jutland; the Angles lived in areas to the south of them in southern Jutland and Schleswig-Holstein; the Saxons were located to the west of them, along the North Sea coastal areas of northern Germany in the Elbe-Weser region; and the Frisians inhabited the area of coastline between the Saxons and the mouth of the River Rhine in the modern Netherlands.

As the name East Anglia suggests, the heathen Germanic peoples who arrived in and eventually came to dominate the area were mainly Angles. The Saxons did give their name to the areas of southern England known as Wessex, Sussex, Middlesex and Essex, the names referring respectively to the West, South, Middle and East Saxons. But the rest of England, and southeastern Scotland, were dominated by Angles, with the easternmost of these people being located in Norfolk and Suffolk.

Unsurprisingly, there are therefore no place-names in East Anglia indicating occupation by Angles, because there would have been nothing distinctive about that. For place-names showing an Anglian presence we have to travel west to areas which were predominantly occupied by Saxons, where Angles were unusual. For example, the name of the Wessex settlement of Englefield, now in Berkshire, meant the 'field of the Angles' - which tells us rather clearly that most people in Wessex were not Angles.

East Anglia, however, did have something of an ethnic mix: there were not only Angles there. The name of the Suffolk village called Saxham, near Bury St Edmunds, meant 'the home of the Saxons' (Briggs \& Kilpatrick, 2016; Briggs, 2020a). The village was obviously called that because there was something a bit different in Suffolk about being a Saxon. There were also Frisians: we can see this from the Suffolk village names Friston and Freston, 'village of the Frisians'. Indeed, in his paper "The Frisians in East Anglia", the American sociologist George C. Holman argues that "Frisians invaded East Anglia in the fifth century", and that East Anglia "is culturally more closely related to Friesland than it is even to its nearest English relative, Kent" (1962: 181). There were also other Germanic peoples present: Swabia today is the part of Germany around Stuttgart, but some Swabians must have been part of the cross-North Sea migration because the name of the Norfolk town of Swaffham meant 'the home of the Swabians'. Flempton in Suffolk, also near Bury St Edmunds, may indicate the presence of Flemings, who came from areas inland from the Frisians.

In addition, Hines (1984) argues that there is archaeological evidence to show that colonists from southern and western Norway also settled on the east 
coast of England from around 475, thereby opening up the way for later widespread Scandinavian influence on 6th-century Anglian England. Hines (2013: 38-9) writes that "the Germanic cultures appearing in East Anglia come from right around the North Sea, from the southern littoral - the areas of Frisia and Saxony - to Jutland and well up the west coast of Norway".

\subsubsection{The beginnings of English}

If we were to ask when English first came into being as a language, what we would really be asking is when it started breaking away from the other West Germanic languages, and especially from Frisian, which is its closest relative: linguists have postulated a possible earlier common language, Anglo-Frisian. The West Frisian language is still spoken today in West Friesland, the northwesternmost part of the Netherlands, ${ }^{12}$ and it was long recognised as being a language rather similar to English: East Anglian fisherman had a rhyme which went

"Bread, butter and green cheese

Is good English and good Friese.”

Frisian sea-faring folk, too, still have a version of the same rhyme:

"Bûter, brea en griene tsiis

Is goed Ingelsk en goed Fries.”

A reasonable answer to the question about the beginnings of English would then be that the language began to acquire a separate identity of its own once the speakers of West Germanic, who had originally crossed the North Sea from mainland Europe as mercenaries during the Roman occupation and as raiders, first started to overwinter and then settle permanently in Britain. It was the permanent settlement of these people in eastern Britain which was eventually to lead to the break-up of the West Germanic dialects into separate languages, and thus to the development of the English language.

East Anglia lay immediately across the North Sea from the coastline of the original area occupied by these West Germanic peoples, and it was therefore one of the very first British places where they settled. It is also the area with the lowest level of survival of Romano-British place-names (Cox, 1975), which can

12 The related North Frisian language is now spoken along the western coastline of SchleswigHolstein, Germany, immediately to the south of the Danish border, and on the neighbouring off-shore islands. This area was settled from the Frisian homeland in the Middle Ages. East Frisian also still survives as a tiny language island in the Saterland, Lower Saxony. 
be interpreted as being due to much heavier Germanic immigration to the region than to elsewhere in the English southeast (Nielsen, 1998). East Anglia is, too, the area where the largest concentration of early Old English (pre-650 AD) runic inscriptions has been found, for example at Binham and at Spong Hill by North Elmham in north Norfolk; and at Undley, near Lakenheath, in Suffolk (Page, 1999). We can say with some assurance that East Anglia was one of the earliest English-speaking places in the world, and very possibly even the very first place. Certainly, the oldest piece of written English ever discovered anywhere - a runic inscription on a piece of bone - was found in the Anglo-Saxon graveyard in Caistor just outside Norwich. It dates from the 400s AD, and consists of the single word RAIHAN 'roe deer'. ${ }^{13}$

\subsubsection{The first East Anglia}

East Anglia was an independent Anglian kingdom for more than three centuries, from the mid-500s onwards (Hines, 2013). The earliest Germanic rulers of East Anglia were members of the Wuffingas dynasty, which seems to have emerged from the military struggle against the Celts which took place during the course of the $6^{\text {th }}$ century (see 1.1). The name of the dynasty supposedly comes from the name of the - probably historical - King Wuffa. The - definitely historical - Rædwald, who was probably Wuffa's grandson, became King of East Anglia from about 599. Rædwald, who was regarded as the overlord of the whole of Germanic England, was converted to Christianity; and he is widely thought to be the figure who was buried in the famous Scandinavian-style ship burial at Sutton Hoo, by the banks of the River Deben near Woodbridge, in Suffolk.

Politically, the independent Anglian-dominated Anglo-Saxon kingdom of East Anglia, once it became established, had somewhat indeterminate boundaries, as was typical of the time. These fluctuated "with the fortunes of war and the vagaries of dynastic policy, embracing at times Ely and its dependencies in the Fens, but perhaps excluding - at least initially - the south-west of Suffolk" (Williamson, 2013: 60). Williamson says that it is not known when southern and southwestern Suffolk became fully integrated into East Anglia - he suspects not until after the 9th-century Danish invasion. But in the event, East Anglia was eventually bordered to the west by the Kingdom of the Middle Angles - which included Cambridgeshire, Huntingdonshire and Northamptonshire as well as Lincolnshire, and later became part of the Kingdom of Mercia; while to the south lay the

13 The engraved bone can be seen in Norwich Castle Museum. 


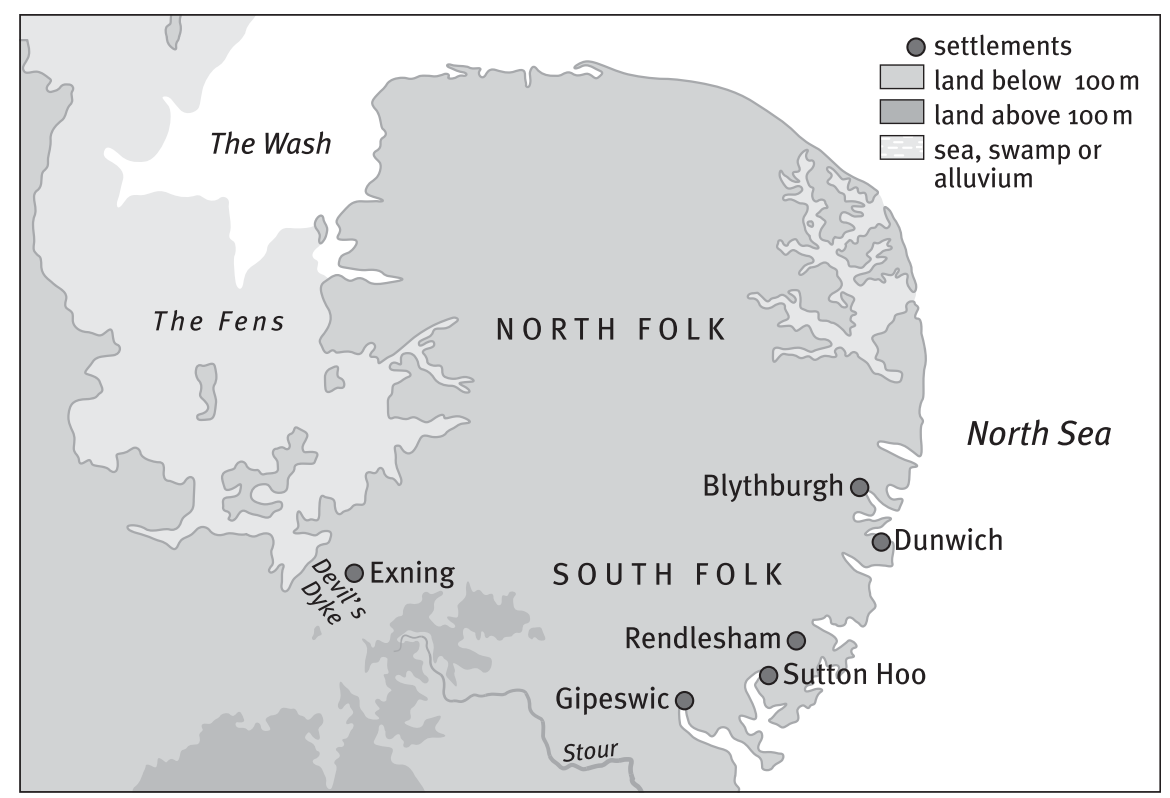

Map 1.1: Early East Anglia.

Kingdom of Essex, which also included eastern Hertfordshire and Middlesex. Williamson (2013: 58) suggests that the Kingdom of Essex might also initially have included southern and southwestern Suffolk.

Topographically, East Anglia was bounded on the east, north and northwest by the North Sea, the Wash, and the more or less impassable Fens; and elsewhere, ultimately, by "the hard, definable lines provided by rivers" (Williamson, 2013: 62) - the Ouse, Lark and Kennett to the west; and the Stour, which still forms the boundary between Suffolk and Essex, to the south. The Kingdom of East Anglia later expanded further west as far as the River Cam, which runs through Cambridge. The area between the Cam and the headwaters of the Stour, where there was no river to demarcate a boundary, was eventually protected by defensive dykes, whose still visible surviving remains have been known in modern times as the "Devil's Dyke" (see Map 1.1). These defences seem to have been aimed mainly at preventing incursions from the neighbouring and much bigger and stronger Anglian kingdom of Mercia.

After Rædwald's death in about 624, East Anglia came increasingly under attack from Mercia, which had acquired control of the Midlands of England stretching from the Thames in the south to the Humber in the north, with its capital in Tamworth, Staffordshire. A number of Rædwald's kingly descendants were killed 
in battle with the Mercians, including Sigeberht (d. 641). Other kings of East Anglia who we know of (Naismith, 2013) include Ealdwulf (663-c.713), Ælfwald (713-749), Æthelberht I (749), Beonna (c.749-760?), Æthelberht II (779?794), Eadwald (796-c.800), Æthelstan (c.825-845), Æthelweard (c. 845-55), and Eadmund (c. 855-869).

Newton (1993) has argued that the famous Old English epic poem Beowulf may well have been written in the independent kingdom of East Anglia, and specifically during the reign of King Ælfwald. Rendlesham in Suffolk has been suggested as the possible place of the original composition; and Newton indicates that certain passages in the poem reflect a particularly East Anglian perspective. Ælfwald was the last king of the Wuffingas dynasty. He had succeeded his father Ealdwulf, who had ruled for almost fifty years; and the combined reigns of father and son seem to have represented a long period of peace and stability in East Anglia, which was perhaps brought about in part by prosperity resulting from commerce between Gipeswic (modern Ipswich) and the German Rhineland. King Æthelberht was killed by the Mercians in 794, and the region briefly became part of Mercia until, after the death of the famous Mercian king Offa in 796, it became independent once again, initially under King Eadwald.

The East Anglian kingdom continued in independence for a number of decades until the Great Viking Army of Danes invaded the region in 865: the army of the East Angles was defeated by the invaders in 869, and the East Anglian king Eadmund, who had been ruling since about 855, was killed. The onomastician Keith Briggs (2011) has argued that Hægelisdun, where Eadmund was slain, was situated near Maldon in Essex. ${ }^{14}$ A shrine supposedly containing Eadmund's remains was later constructed at Bury St Edmunds in Suffolk. The East Anglian kings Oswald and Æthelred then "probably ruled as Viking quislings after Edmunds martyrdom” (Naismith, 2013: 137).

\subsection{Old Danish}

Large-scale Viking settlements took place in England during the 9th and 10th centuries, leading to many eastern and northern areas of the island containing a heavily Scandinavian or Scandinavianized population, as famously witnessed by the hundreds of Norse place-names (see below). The numbers of Scandinavians who actually arrived and settled in Britain is unknown and the subject of

14 A widespread assumption has been that Hægelisdun was Hellesdon, near Norwich. I find Briggs's argument in favour of the Essex site persuasive. 
much controversy (Härke 2002; Holman 2007). But from about 890 onwards, East Anglia became officially part of the Danelaw - the area of England which had been signed over to the Danes by Alfred, the King of Wessex. After the East Anglian defeat, parts of East Anglia were "shared out to Danish Viking soldiers, who were thereby transformed into settlers" (Nielsen, 1998: 167); large numbers of further settlers subsequently arrived from Denmark in a secondary wave.

Prior to 869, the Anglian-origin English language of East Anglia had developed gradually, with little outside influence, for about four hundred years, but now the area became bilingual again, although there remains the interesting question as to what extent bilingualism as such would actually have been necessary. The original parent language of Old Danish, North Germanic, was a close relative of West Germanic; and indeed many linguists postulate an earlier language which was ancestral to both, Northwest Germanic, which would have split up into North and West Germanic around $450 \mathrm{AD}$ (Kuhn, 1955). ${ }^{15}$

It is therefore quite possible that English speakers and Danish speakers could still understand one another reasonably well during the 9th, 10th and 11th centuries even without becoming particularly bilingual as individuals. Indeed, Townend (2002) has shown that there is plenty of evidence to suggest that there must have been a considerable degree of comprehensibility, and that communication may not have been too difficult, especially after long periods of contact had made each group familiar with the speech patterns of the other. Townend asks, when the 9th-century Stockholm Codex Aureus was recovered from Viking hands by the English: "what were the linguistic means by which Ealdorman Aelfred negotiated with the Vikings for the recovery of the gospelbook?" (2005: 4). He cites very many other examples of contacts between Norse and English speakers where the individuals involved use language to do things like making treaties, buying land, negotiating contracts and marriages, and settling disputes, to the extent that it is impossible to conceive that they would have been able to do this without being able to understand one another to a fair degree. No interpreters or translators are ever mentioned, as they often are when communication between speakers of other languages is being described.

Bidialectalism, then might well be a better description than bilingualism for the situation in 10th-century East Anglia. It was probably mostly passive bidialectalism, however. Townend argues that the situation was one of adequate intelligibility, meaning "amongst other things, the ability to understand individual words, if this ability was sufficiently widespread and sufficiently successful

15 The other branch of the Germanic language family was East Germanic, which was the family to which the Gothic language belonged. 
to permit face-to-face and day-to-day transactions, and so to preclude the need for one or both of the speech communities in the Danelaw to become bilingual, or for interpreters to be habitually used for the purposes of Anglo-Norse communication" (2005:183).

In spite of the fact that the Danelaw soon came back under English control (in 917 - see 1.5), very large numbers of Danes stayed on in East Anglia; and according to Sandred (2001: 45), "the Scandinavian impact on the language [of East Anglia] must have been considerable”. There was certainly also considerable influence from Danish culture on English culture: archaeological finds "demonstrate the clear impact Viking forms of culture exerted in East Anglia” (Pestell, 2013: 255). But it is an interesting question as to how much Danish was spoken in East Anglia, and for how long. Very many words of Scandinavian origin are in general use in modern English, but in East Anglia, as in other parts of Britain where Norse settlement was heavy, an even larger number of words from Old Norse survive to this day in local speech (see more on this in 5.1.4).

One example from Norfolk and Suffolk ${ }^{16}$ is beck 'stream' - the modern Danish word is bæk. Another is staithe, from Old Norse stǫð 'landing stage' cf. modern Norwegian stø: in central medieval Norwich there were eleven landing stages called staithes, which "throws particular light on the role of the city as an early market and port” (Sandred, 2001). There are also many Old Norse-origin placenames in the area: for instance, toft, as in Lowestoft, ${ }^{17}$ meant 'plot of land' cf. modern Norwegian tuft; and the Old Danish form kirk 'church' is also found in Norfolk (Kirby, Kirstead) and Suffolk (Kirkley).

These Scandinavian place-names can help to provide us with evidence concerning the geographical and chronological extent of the usage and survival of Danish in East Anglia. When the first Danes arrived, the Angles had of course already been occupying many of the most productive areas of the region for many centuries; and the linguistic evidence suggests that Vikings often therefore had to settle in areas which were less desirable in some way. Fellows-Jensen tells us that "the only areas from which Old English place-names are absent are the most marshy and inhospitable ones so that Danes arriving in the late ninth century cannot have found much easily exploitable vacant land". Marshy and inhospitable areas were certainly to be found around the estuary of the River Yare, and "a marked concentration of Scandinavian names is to be found at the eastern end of the Norfolk/Suffolk boundary, in the hundreds ${ }^{18}$ of Flegg and Lothingland"

16 Cambridgeshire and Essex saw lower levels of Danish settlement.

17 The specific element of this name comes from the Scandinavian personal name Hlódvér.

18 'Hundred' was the old Germanic label for a subdivision of a county, in use in England until 1894. 
(2000: 48). Lothingland was originally an island which was bounded to the north by the River Yare and Breydon Water; to the west by the River Waveney; and to the south by what is now Oulton Broad and Lake Lothing (near Lowestoft) but which was then another branch of the Waveney.

According to Fellows-Jensen, the Danish place-names in Lothingland are quite varied, with forms in -holmr 'island of higher ground in a marshy area' being the most frequent. On the north side of the Yare estuary, Flegg too was an island at that time. The rather dense settlement of Flegg by Danes is revealed in the extreme concentration, unparalleled anywhere else in the region, of placenames ending in -by 'settlement': Ashby, Billockby, Clippesby, Filby, Hemsby, Herringby, Mautby, Oby, Ormesby, Rollesby, Scratby, Stokesby, and Thrigby (by is now the Danish and Norwegian word for 'town' and the Swedish word for 'village'.) Flegg itself is also an Old Danish word referring to a boggy area overgrown with marsh-plants such as iris (flag).

Place-names in -thorpe originally indicated smaller outlying Danish villages dependent on a by. A number of Norfolk names with the generic -thorpe have specifics derived from Old Danish personal names: Ashwellthorpe, Pockthorpe (there are several of these, including one in Norwich), Ingoldisthorpe, Glosthorpe (in Denmark there are two places with the same name, Glostrup), Calthorpe (cf. Kallerup in Denmark) and Freethorpe. This pattern is also found in Akethorpe in Suffolk. However, thorpe was later borrowed into Old English, and Besthorpe in Norfolk may well have an Old English specific (Fellows-Jensen, 2000).

A complicating factor, though, is that some Vikings also seem to have taken control over already established Anglian settlements. The linguistic evidence for this is thought to be provided by the so-called "Grimston hybrid" place-names: Grimston in Norfolk has the Old English ending -ton prefixed by the Danish man's name Grim. Suffolk Grimston hybrids include Thurlston, from the Scandinavian name Thorulf, and Thrandeston from Thrond. But what exactly do these hybrid names signify? Does the hybrid name of Aslacton in Norfolk signify an established Anglian village which was seized by a Viking called Aslak, who renamed it after himself? Or did Aslak simply establish a new village and give it a partly English name which fitted in with the names of the other settlements he now found around him (Parsons, 2006)? It certainly seems to be the case that in terms of soil quality and habitability, when it comes to villages with Scandinavian names, Grimston-hybrids are found on the most desirable sites; the -by names on the second best sites; and the -thorpe names on the least desirable.

The possible take-over by Danes of English settlements may also be suggested by other types of hybrid such as the two Ashbys (one in Flegg, one in south Norfolk), which derive from Old English æsc 'ash-tree'; Wilby (in southwest Norfolk), which derives from English wilig 'willow'; and Aldeby (on the 
north bank of the River Waveney), which contains the Old English adjective ald 'old'. Fellows-Jensen also suggests that the names of the Norfolk villages of Kirby Bedon and Kirby Cane indicate the taking-over by the Danes of English settlements which already had churches, and adds that "there is certainly AngloSaxon fabric in the church at Kirby Cane” (2000: 49).

The Danes also established a considerable urban presence. Norwich was actually ruled by the Danes from 870 to about 925 (Campbell, 1975); Thetford in Norfolk also became a mainly Viking town; and there were a high proportion of Scandinavians in Ipswich. There are still many streets in Norwich whose names end in -gate, the Scandinavian word for 'way, street': Bishopgate, Colegate, Cowgate, Finkelgate, Fishergate, Pottergate, Mountergate, and Westlegate. There were formerly a number of others, as recorded by the Swedish scholars Karl Inge Sandred \& Bengt Lindström (1989), such as Hundegate, Neugate, and Saddlegate. Tombland, an open space by Norwich Cathedral, which was the site of the AngloDanish market until the Norman invaders (see below) moved it, takes its name from Scandinavian tom 'empty'. ${ }^{19}$ In Thetford there are streets called Eastgate, Minstergate, and Redgate.

Another interesting set of clues as to the longevity of Danish comes from the numerous field-names of Nordic origin to be found in East Anglia (Sandred, 2001), including names in wong 'meadow', sty 'path', and how 'hill' (the modern Norwegian equivalents are vang, sti, and haug). In fact, studies of field-names, and other minor names of different localities, seem to suggest, for Norfolk at least, a wider, stronger and perhaps more persistent Scandinavian linguistic presence than the major town and village names alone might indicate. Sandred writes that the study of minor names reveals "Scandinavian influence in an area [of western Norfolk] where there are no traces of Scandinavian influence in the major names" (Sandred 1979: 115).

Parsons (2006) similarly writes that the relative richness of Old Norse fieldname evidence in Holt and North Erpingham, North Norfolk, is an important indication that Scandinavian influence there was greater than might be deduced from the village names alone. He used Sandred's research to carry out a fascinating study of minor names in which he compared forms in the two Flegg Hundreds in eastern Norfolk with those in the northern Hundreds of Holt and North Erpingham. The northern Norfolk hundreds have names with kjarr 'carr, boggy wood' and lundr 'grove', as well as tveit 'clearing'; and Parsons' statistical work shows that there were not significantly fewer Old Danish names in north Norfolk

19 The in the modern spelling is unetymological. The name is most often pronounced /tu:m'lænd/. 
than in the more obviously Danish-influenced Flegg: in both areas, Old Norse forms provide the generic element of nearly $20 \%$ of minor place-names. Amongst Scandinavian-origin specifics in earlier minor place-names, Parsons notes old Norse steinn 'stone' in the name Magna Steyndale in Plumstead near Holt, from around the year 1300; and the form mikill 'much' in Myklecrundell, also from around 1300, in nearby Edgefield. Edgefield also had a traditional Old Norse personal name as a specific in the name Gunilduscroft, and there is another, Hethincroft, in nearby Sharrington.

This usage of minor names of Danish origin alongside English-origin names suggests at least a very considerable amount of language/dialect contact between speakers of Old English and speakers of Old Danish, probably lasting for many generations. In fact, place-names in eastern Norfolk indicate that Old Danish speakers in Flegg were probably surrounded by people who spoke Old English. To the north of the Flegg Hundreds was the Hundred of Happing, an Anglo-Saxon name meaning 'the followers of a man called Hæp', whose name also appears in Happisburgh, ${ }^{20}$ dating back to an Anglo-Saxon settlement which had been there for four centuries before the Vikings arrived. And Flegg's other neighbour across what is now the River Bure, Walsham Hundred, also had an English-language name: it meant the hām (modern 'home') or homestead of an Anglian leader called Walh or Wæls (Ekwall, 1960: 494).

The Scandinavians perhaps did not even have Flegg all to themselves. It looks like there may have been an ethnolinguistic dividing line across the island since, immediately to the north of Hemsby, Rollesby and Ashby, there are places with names like Bastwick and Martham which go back to the original Anglo-Saxon settlement period.

It is not possible to be sure about the exact location of any ethnolinguistic boundary: Repps, in the Danish-English borderlands between Bastwick and Ashby by the river Thurne, is thought by some experts to be an English name related to the Anglo-Saxon word ripel meaning 'a strip of land'; but others maintain that it is from Old Danish rep meaning 'community'. The name of the nearby River Thurne is also linguistically ambiguous. The river is named after the village of Thurne, which comes either from Old English thyrne meaning 'thorn bush', or from Old Norse thyrnir with the same meaning. In any case, it is reasonable to assume that there was communication between the two language groups in Flegg; and that the sort of bilingualism/bidialectalism developed which must also have occurred in other areas in order to lead to, for example, the maintenance of Old Norse-origin field-names.

20 The modern pronunciation of Happisburgh is /heizbra/. 
Also in favour of the presence of Old Danish-Old English bilingualism/bidialectalism is Perridon (1997: 360), who writes that, while it is well known that Old Norse had a major impact on English, it has not been so usual to suggest that "dialect contact in the Danelaw might have had some consequences for the invaders as well". The point is that there are a number of similarities between English and the Danish dialects of West Jutland which might well have such an origin: Perridon specifically mentions the fact that varieties on either side of the North Sea both lost grammatical gender. He explores the interesting possibility that these two gender-simplification events, in Britain and in West Jutland, might be linked in the sense that the former may in some sense have exported it to the latter. Russ (1982) has made a similar suggestion.

In discussing how this carrying back of linguistic innovations from England to the Danish homeland might have taken place, we can note the relative geographical proximity of East Anglia and Jutland: from Yarmouth in Norfolk to Esbjerg in Denmark is 297 nautical miles, a distance which could be covered by some Viking ships in less than 24 hours under favourable conditions (Winroth, 2014: 72). Perridon also mentions (1997: 261) that "West Jutland mainly consists of barren moorlands, which in the past could hardly sustain its population", which might have led to a large number of people from this area emigrating to England, and "it is not unreasonable that those who returned to West Jutland, after having accumulated some wealth in England" could have been, as successful bilingual/bidialectal remigrants, rather influential.

Townend (2002) suggests that Old Norse probably died out in northern England in the 1200s, and it is therefore likely that Old Danish as such had disappeared from East Anglia, which was less heavily Scandinavianised than the north, before that. But it is not at all impossible that Old Danish, or at least an anglicised contact-form of the language, continued to be spoken in East Anglia to an extent until the 12th century (Dance, 2014; Parsons, 2001; Kisbye, 1992). As Parsons says, however, "we are very poorly informed on the crucial question of how long Norse survived anywhere in eastern England" (2006: 175).

We do know, though, that eventually the speakers of Norse did abandon it in favour of English - an English, however, which by then had as a consequence of English-Danish bilingualism/bidialectalism become considerably Norsified. In fact, "abandon" might well not be the most appropriate word here at all. In view of the at least quasi-dialectal nature of the relationship between Old English and Old Danish, we would probably do better to think of the descendants of the Viking invaders gradually modifying their Old Danish over the generations in the direction of Old English. Especially if Old English speakers in a bilingual town like Norwich also gradually modified their dialect in the direction of Old Danish, then there would have come a point where the two became no longer distinguishable. 
Emonds \& Faarlund (2014) claim that the Germanic language which eventually emerged out of language contact between Old English and Old Norse in early medieval England was in fact not Norsified English but Anglified Norse a Scandinavian language heavily influenced by Old English. Modern English, they argue, should therefore be considered to be a Scandinavian language. They argue their case using mainly syntactic data, citing the Norse character of a number of Middle English ${ }^{21}$ syntactic constructions as compared to Old English. They point out, for example, that van Riemsdijk (1978) makes the strong claim that the only languages in the world which permit grammatical constructions with fully developed preposition stranding ${ }^{22}$ are, firstly, members of the North Germanic language family and, secondly, English: Danish Reven ble skutt på ['Fox-the was shot at'] is entirely paralleled by English The fox was shot at (Holmberg \& Rijkhoff, 1998). According to Emonds \& Faarlund, most languages disallow this construction completely; and West Germanic Dutch allows it only "under very restrictive conditions" - which was also the situation in Old English. According to Hoekstra (1995), it is also disallowed in Frisian. ${ }^{23}$

However, in view of the scenario we have outlined above of the gradual melding of the two Germanic dialects into one, the opposition between Anglified Norse and Norsified English would seem to be a distinction without a difference. Le Page \& Tabouret-Keller pointed out (1985) that languages can be sociolinguistically more or less diffuse or focussed. In diffuse linguistic communities, little codification has taken place; there is little agreement about norms; little concern for demarcating the language variety from others; and relatively little importance is accorded to what the language is called. In focussed communities, codification has taken place; there is a high degree of agreement about norms; speakers show concern for demarcating their language variety from others; and there is agreement about the language's name.

Viking Age England was a much more linguistically diffuse than focussed place. People walking around, say, 10th-century Norwich would just have been speaking to each other in such as way as to ensure the best possible communication. Very few of them would have had any clear notion of the sociolinguistic situation as being one of bilingualism, and there is no reason for us to have that perception either. The single Germanic language which eventually emerged in

21 The Middle English period is often defined as having lasted from c.1150 to c.1470.

22 In The boy I gave it to, the preposition to is said to be "stranded" at the end of the sentence, as opposed to in The boy to whom I gave it.

23 For a discussion of the work of scholars who have suggested possible Brittonic influence on the development of English preposition stranding, see Roma (2007). 
medieval East Anglia really was descended from the language of the Danish Vikings; but it was also descended from the Old English dialects of Anglian Norfolk and Suffolk.

\subsection{Anglo-Norman and Middle English}

In 903, the East Anglian Danes allied themselves with Æthelwold of Wessex in an uprising against the King of England, Edward the Elder. They were eventually defeated, with the result that by 917 East Anglia had come under the total control of the kings of England and ceased to exist as an independent AngloDanish polity. As part of the Kingdom of England, however, East Anglia did then became a separate earldom.

From 1016, during the reign of King Canute, himself a Dane, the Earl of East Anglia was Thorkell the Tall, a Swedish-Danish noble from the Baltic Sea region. But he was succeeded by a series of mostly Anglo-Saxon Earls of East Anglia, including Harold Godwinson - the later King Harold who was defeated by the Normans at the Battle of Hastings. As their name suggests, the Normans themselves were originally Scandinavian Vikings. Only a few generations earlier they had been Old Danish speakers, but had subsequently shifted to French.

After the Norman conquest of England in 1066, Norwich, the capital of East Anglia and by now a rather sizeable town with a population approaching 7,000, was a rather multilingual place. In addition to the original speakers of English, there would probably still have been speakers of a form of Danish, mostly descendants of the original 9th-century influx, but also perhaps people who had come over from Denmark with King Cnut when he became king of England in $1016 .^{24}$ There were certainly also speakers of the newly arrived Norman French. And the Normans brought with them from the continent large numbers of speakers of other languages, especially Flemish (Dutch) from the Low Countries, and Breton.

Many Jews also arrived with the Normans as well as subsequently. They were probably mostly speakers of Norman French, and would for the most part have remained so until they were expelled from Britain in 1290. They also had a knowledge of Hebrew as their liturgical language and language of scholarship. One of the most famous of all medieval Jewish poets lived in East Anglia: he is known to Jewish scholars today as Meir ben Elijah of Norwich. ${ }^{25}$

24 After his conquest, Cnut paid off his soldiers, who mostly went back home again to Denmark. 25 His works are now available in an English translation by Ellman Crasnow \& Bente Elsworth (see Pim et al., 2013). 
In 1144, a 12-year-old boy called William was murdered on the outskirts of Norwich and his body found on Mousehold Heath. There was a belief at the time "- the blood libel" - that Jews carried out ritual murders of Christian children, and Norwich citizens falsely accused the Jews in the city of killing William. William was turned into a martyr through this anti-Jewish racism, and a chapel dedicated to him was built on Mousehold - the ruined foundations are still visible. This was a manifestation of the same bigotry which later led to the slaughter of Jews in Norwich in 1190, and to the expulsion of the Jews from England by King Edward I in 1290. There was also quite possibly a linguistic component to the hostility which was directed towards the Jews. William was a Christian boy who spoke English; the Jews, like the Norman overlords, were (as just noted) speakers of Norman French - they were set apart from the English by their language as well as by their culture and religion.

Following the Norman Conquest, Ralph de Guader was appointed Earl of East Anglia and began the work of building Norwich Castle. He had been born in England and was half Breton and half English, but he fought on the side of the Normans in 1066. He was also known as Ralph de Gaël, after lands he owned in Brittany, as well as Radulf Waders and Ralph Wader. We can suppose he spoke English, Breton and Norman French. In 1069, Ralph defeated a Danish force which had invaded Norfolk and briefly taken control of Norwich. It may have been in recognition of this that the King, William the Conqueror, made him Earl of Norfolk and Suffolk (he was also known as Earl of Norwich, and Earl of the East Angles). However, Ralph was later involved in the Revolt of the Earls against King William, and when this revolt was crushed in 1075, Ralph retreated to Brittany, and the Earldom of East Anglia was abolished. Ever since 1075, then, East Anglia has been a concept rather than an area with any legal or official status.

The Norman French language of England, often referred to as Anglo-Norman to indicate the extent to which it came to differ from the language of Normandy, survived as a minority upper-class spoken language in England until the 14th century. From the mid-1300s onwards, however, English started making more of an appearance as a written language, which greatly facilitates our research into the nature of the English dialects of that time. We can see, for instance, that London was gradually becoming a site of considerable dialect contact and dialect mixture. Lass (1999: 3) writes of a "demographic movement that also had linguistic effects: an internal 'invasion' of London and the Southeast, especially from the North and East Anglia, which from late Middle English times onward left in the emerging standard and related varieties a number of items which are clearly not native to" the Southeast. 
A good proportion of the in-migrants into the ever-expanding city of London were East Anglians. This is no surprise, given that "from the eleventh to the fifteenth century and beyond, East Anglia was the wealthiest and most heavily populated area of the kingdom, with the walled circuit of its regional capital, Norwich, encompassing a greater area than that of London" (Liddiard, 2013: 9). Norwich for centuries had the second largest population of any city in the land. Wright (2001) shows that it was only in London and Norfolk that 14th-century guild certificates were written in English, underlining the status of (at least northern) East Anglia as an area of high population density and language contact: "the fashion for abandoning Latin and French and using English began in the centres of commodity and exchange" (Wright, 2001: 100).

Ekwall (1956) too says that many wealthy merchants (as well as goldsmiths, clerks and others) migrated to London from East Anglia; and Kristensson (2001) suggests that social-class dialects began to develop in London at about that time, with upper-class speech patterns - hence the influence on the "emerging standard" - being derived in part from East Anglia. Three of the in-migrants to London from Norfolk became mayors, and seven of them became Members of Parliament for London.

There are many Modern English linguistic forms which do not derive from the native London-type Essex or Kentish dialects but from dialects found in areas to the north of the Home Counties - and therefore in part from East Anglian speech. They include items such as fen rather than London ven; street rather than strate; miller rather than meller; milk rather than melk; flax rather than vlex or flex; and old rather than eld. They also include Old Norse-origin forms, which were more prevalent in the former Danelaw, such as them rather than hem, again rather than ayaine, and give not yeve, plus Old Norse borrowings such as get; Kristensson suggests that East Anglian incomers were one important conduit into London for these Scandinavianisms.

\subsection{Flemish and Walloon}

In the 16th century, a major linguistic event occurred in East Anglia which again involved immigration from across the North Sea. From the 15th century onwards, the different provinces of the Low Countries (which are for the most part now Belgium and the Netherlands) had come gradually under the control of the Dukes of Burgundy. Mary, the daughter of Charles the Duke of Burgundy, then married Emperor Maximilian of Austria. Their son Philip married Joanna, the daughter of Ferdinand of Aragon and Isabella of Castile, and so control of the Low Countries ultimately passed to their son, who as Charles V was Holy 
Roman Emperor but was also King Charles I of Spain. When he abdicated in 1556, the Empire went to his brother, Ferdinand I; but the crown of Spain went to his son, King Philip II, together with control over the Low Countries.

Although Charles had been educated in the Low Countries, his son Philip was brought up in Spain and was a devout Catholic. Most of his domestic, colonial and foreign policies were focussed on stamping out Protestantism, so it was inevitable that there would be trouble in the Low Countries where Calvinism had taken root in the northern provinces (now The Netherlands). Under the control of Philip's sister, Margaret of Parma, Spanish troops were stationed in the Low Counties and "heretics" were prosecuted by the Spanish Inquisition. This led to an insurrection against Spanish domination, which even involved the still mainly Catholic south (modern Belgium), where loss of autonomy was resented.

Persecution by the Spanish led to Dutch, Flemish and Walloon refugees fleeing to Protestant England. Many of them settled in Sandwich (Kent), London and Colchester, but by far the biggest group of refugees found their way to Norwich. They were probably attracted at least partly by an already established group of Flemish weavers there. ${ }^{26}$ The refugees themselves, although predominantly also textile workers, included ministers, doctors, teachers, merchants and craftsmen. The very high proportion of Strangers 'foreigners' in the city did lead to a certain amount of friction, and there was at least one attempted revolt against them; but generally, the absorption of a very large number of refugees into the population, while undoubtedly causing overcrowding, was relatively trouble-free. By 1579, remarkably, 37\% of the population of Norwich, which at that time was 16,236, were not native speakers of English. Colchester at the same period had a population of around 6,700, with around 1,300 or about $19 \%$ of this number being refugees from the Low Countries (Goose, 1981).The refugees were mostly Dutch speakers from Flanders and Brabant, but there were also French-speaking Walloons from Armentieres, Namur and Valenciennes (at this period, the border with France was further south than it is today), and even some German speakers from Lorraine.

According to Moens (1888), "in the first half of the 17th century, as much Dutch and French was spoken in Norwich as English”, which cannot exactly have been true. But orders for the conduct of the Strangers were certainly written in French in 1659. And the first books ever printed in Norwich were written

26 In 1565, the mayor and aldermen of Norwich had invited 30 "Dutchmen" and their families - no household was to exceed ten persons - to Norwich in an attempt to modernise the local textile industry, which had been lagging behind in terms of technology, design and skills: 24 Flemish and 10 Walloon master textile makers arrived and settled in Norwich. 
in Dutch; their printer was Anthony De Solempne, who had been a spice merchant in Antwerp and had arrived in Norwich as a religious refugee in 1567. Soon after arriving, he was operating a printing press in the parish of St Andrew in Norwich, and he produced two books in Dutch in 1568. These were "an edition of the psalms and some prayers in metre translated by Petrus Dathenus together with a catechism for the use of the Dutch Reformed Church" and "a reprint of a Dutch translation of the Confession of Faith drawn up by the Swiss Reformed Church and subsequently studied by some of the Dutch Calvinists" (Stoker, 1981).

East Anglia even produced some poets of note who wrote in Dutch (Joby, 2014). The best known was Jan Cruso, who also wrote in English. He was born in Norwich in 1592 of parents who had come from Hondschoote in Flanders ${ }^{27}$ in the 1570s, and he probably went to the Norwich School. He spent several years in London, but was back in Norwich by 1620, where he ran the family cloth business. He was also a member of the local militia, and a church elder. ${ }^{28}$ One of his poems runs, in part:

Ja d'wijl ick dit beschrijv', en in de groene dalen

Langst Yeri koele stroom ick gae een lochtjen halen

En keere na de Stadt de dichte Bosschen door,

Hoe word' ick daer onthaelt van 't Nachtegalen Choor. . .

'And whilst I write this, and in the green valleys

By the Yare's cool stream, I get a breath of air

And return to the City through the thick Woods,

I am entertained by the Choir of Nightingales. . .' [Joby, 2014: 196]

Until the $18^{\text {th }}$ century, Calvert Street in Norwich was known as Snailgate, but during the $17^{\text {th }}$ century the street more often went by the name of Snackegate in older Dutch dialects snek was a word for 'snail'. According to Ketton-Cremer (1957), church services in Dutch and French were maintained for many decades in the churches in Norwich that had been given over to the immigrant communities, and the congregations remained vigorous until 1700 or so (Joby, 2015). The French-speaking community in East Anglia was later further strengthened by the arrival of Huguenots from France after the revocation of the edict of Nantes in 1685; and it is clear that Norwich remained a trilingual city for 150 years, into the 18 th century.

27 Hondschoote is now in France, immediately over the border from Belgium.

28 Cruso's brother moved to London and had a son, Timothy, who is said to have given the novelist Daniel Defoe the idea for the name Robinson Crusoe. 
Then, "slowly but inevitably the Strangers became merged into the surrounding population and the community lost its separate identity" (Ketton-Cremer 1957). By 1742 the congregations attending church services were small, and the churches decayed. Dutch and French finally died out of use in Norwich in the 1700s.

Some possible linguistic consequences of this trilingualism will be discussed further in Chapters 4 and $5 .^{29}$

\subsection{Romani}

Another significant linguistic group who arrived in East Anglia during the 16th century, or soon after, were the Romani-speaking Gypsies. Romani is a language - or more accurately a group of languages - belonging to the Indo-Aryan sub-family of Indo-European, whose closest linguistic relatives such as Hindi, Punjabi and Kashmiri are found in the northwestern part of the Indian subcontinent (Matras, 2005).

According to Hancock (1984), the generally accepted date of arrival of Romani-speakers in Britain is 1505 for Scotland and 1512 for England; but Evans (1966) has them arriving in Wales before 1440, and Matras (2010) reports that they may have settled in Scotland as early as 1460. Evans (1966) describes how one of the first records of the Gypsies in England is of the Earl of Surrey entertaining a party of "Gypsions" at Tendring Hall, near Stoke-by-Nayland in Suffolk, in about 1520. And, fascinatingly, Töpf \& Hoelzel (2005) also cite strong genetic evidence from excavations in Norwich for the presence of people of Romani ancestry in Anglo-Danish East Anglia as early as the 900s AD.

According to Matras (2010: 57), "much of the history of the Romani-speaking community in Britain can be traced thanks to sources that provide us both with a description of the community and with a sample of their Romani speech". One important source is an anonymous text from 1798 known as the "East Anglian vocabulary of Romani” (Sampson 1930: 136). Another early source consists of 18th-century material collected by the Norfolk clergyman, Rev. Walter Whiter, who was born in Birmingham but died in 1832 in Hardingham, near Wymondham, ${ }^{30}$ Norfolk. He was known in his day as an etymologist, and his work was familiar to the novelist and travel writer George Borrow (1803-1881), who was born in Dereham, Norfolk, and educated at Norwich School. Borrow lived much

29 The last French-language church service in Norwich was in 1832, and the last in Dutch in Blackfriars Hall in the 1890s, but by then the languages had attained the status of liturgical languages only.

30 Pronounced/windm/. 
of his life in Norwich and also took a great interest in the Romani languages (Hancock, 1997), spending time with Gypsy communities in different parts of continental Europe and Britain, including on Mousehold Heath in Norwich.

During the 19th century, Romani in England was beginning to morph into the linguistic variety now known to linguists as Angloromani. Romani is a highly inflected language, but the original inflectional (though not necessarily derivational) morphology of Romani grammar was gradually being lost during this period. It is true that

sources such as the East Anglian vocabulary of 1798 have [the genitive case] both as a word-compositional device, as in sunekiski chiriklo 'goldfinch', literally 'a bird of gold', or butti iska besh 'working season', literally 'year of work', as well as in the function of a genuine possessive, as in ma duvlasko rokraben 'the words of my Lord' and e greski bošto 'the horse's saddle'.

(Matras, 2010: 71)

And the Norfolk clergyman Whiter's vocabulary has an inflected dative in devleska 'for God's sake'. But this kind of morphology was gradually being replaced by English syntax and grammatical words; and, in the 20th century, Way's vocabulary "collected in East Anglia in 1900 from the Cooper, Lock and Buckland families, shows only few inflected forms” (Matras, 2010: 59), most of which have now gone entirely.

Modern Angloromani, then, does descend "from an inflected dialect of Romani that was spoken in England up to the mid-nineteenth century and perhaps even a generation or two later", but it can be thought of today as a variety which consists mainly of English phonology and grammar, but with a proportion of Romani lexical items. ${ }^{31}$ As such, it can be used as an anti-language, i.e. a language which is intended not to to be understood by outsiders. A brief example from Matras (2010: 6) illustrates the point:

. . .that would sell its wudrus to buy livvinda. You know, they don't

kom these fowkis. . . . Me dad used to say, low life fowkis don't

want chichi, never will have kuvva. Be waffadi all their lives. ${ }^{32}$

There has been some lexical input from Romany into East Anglian English dialects, as will be discussed in 5.4 .

31 For an excellent in-depth analytical treatment of Angloromani, see Matras (2010).

32 ' . . . that would sell its bed to buy beer. You know, they don't like these people. . . . My dad used to say, low life people don't want nothing, never will have any things. Be bad all their lives.' 